\title{
Research Article \\ Effect of Calcined Hard Kaolin Dosage on the Strength Development of CPB of Fine Tailings with Sulphide
}

\author{
Juanrong Zheng, ${ }^{1}$ Lijie Guo, ${ }^{2,3}$ and Zhenbo Zhao ${ }^{1}$ \\ ${ }^{1}$ College of Civil Engineering, Zhengzhou University, Zhengzhou, Henan 450002, China \\ ${ }^{2}$ Beijing General Research Institute of Mining and Metallurgy, Beijing 102600, China \\ ${ }^{3}$ University of Science and Technology Beijing, Beijing 100083, China
}

Correspondence should be addressed to Lijie Guo; guolijie@bgrimm.com

Received 18 March 2017; Accepted 4 June 2017; Published 17 August 2017

Academic Editor: Kedsarin Pimraksa

Copyright (c) 2017 Juanrong Zheng et al. This is an open access article distributed under the Creative Commons Attribution License, which permits unrestricted use, distribution, and reproduction in any medium, provided the original work is properly cited.

\begin{abstract}
This study presents the effect of calcined hard kaolin (CHK) as replacement (15-50 wt.\%) to Portland cement (PC) on the strength development of cemented paste backfill (CPB) of fine tailings containing sulphide. PC is used as binder at 20 wt. $\%$ dosage. The results show that $\mathrm{CPB}$ sample containing $30 \mathrm{wt} . \% \mathrm{CHK}$ replacements produces the desired strength and durability (i.e., $26.1 \%$ increase in strength over the curing period between $28 \mathrm{~d}$ and $360 \mathrm{~d}$ ). CPB without CHK does not produce the desired strength and durability (i.e., $32.8 \%$ losses in strength over the curing period between $90 \mathrm{~d}$ and $360 \mathrm{~d}$ ). The quantity of expansive gypsum of CPB containing 30 wt.\% CHK is obviously less than that of CPB without CHK. The porosity of the fine pore for pore diameter $<0.3 \mu \mathrm{m}$ is obviously higher in $\mathrm{CPB}$ containing $30 \mathrm{wt} . \% \mathrm{CHK}$ than in $\mathrm{CPB}$ without $\mathrm{CHK}$, regardless of curing time. It can be concluded that $\mathrm{CHK}$ can be suitably exploited for $\mathrm{CPB}$ of fine tailings with sulphide to improve the strength and stability in short and long terms.
\end{abstract}

\section{Introduction}

The tailings are usually separated to fine tailings (average particle size less than $0.037 \mathrm{~mm}$ ) and coarse tailings by hydrocyclones in China. The fine parts are generally stored in a surface impoundment [1], whereas the coarse tailings mixed water and a hydraulic binder are transported by gravity into underground voids $[2,3]$. The lead-zinc tailings are often rich in pyrite and contain toxic metals such as arsenic $(\mathrm{As})$, cadmium $(\mathrm{Cd})$, lead $(\mathrm{Pb})$, zinc $(\mathrm{Zn})$, and copper $(\mathrm{Cu})$. The oxidation of pyrite in presence of water and oxygen generates acidity and facilitates the release of toxic metals contained in the tailings $[4,5]$. The finer the granularity of tailings is, the lower the water permeability is, the harder the drainage consolidation is, and the easier the spill of the storage tailings dam is [6]. The spill of the storage tailings dam will lead to increasing the heavy metal content in the downstream soil, acidizing the soil, reducing organic matter content in the soil, and hardening the soil $[7,8]$. In recent years, cemented paste backfill (CPB) of potentially hazardous mill tailings into underground and surface disposal practices has gained importance for the environmental management of such wastes $[9,10]$. Environmental problems associated with the storage of sulphide-rich wastes under atmospheric conditions (i.e., the formation of acid mine waters and the release of heavy and toxic metals with the concomitant risk of contamination of soils and underground/drinking waters) can be considerably reduced by the placement of such wastes safely in underground.

$\mathrm{CPB}$ is essentially an engineered mixture of wet fine mill tailings (75-85\% solids by weight), a hydraulic binder (3-7\% by dry total paste weight), and mixing water. However, some potentially long-term durability problems of $\mathrm{CPB}$ may be encountered when mill tailings with high sulphide (especially pyrite) content are used. Oxidation products (i.e., acid and sulphate) of sulphide minerals present in the tailings could lead to chemical reactions with hydration products and binder phases, such as calcium hydroxide $(\mathrm{CH})$ and calcium aluminate $\left(\mathrm{C}_{3} \mathrm{~A}\right)$ and, concomitantly, to the formation of expansive phases such as ettringite and gypsum [11-15]. These could then culminate in the reduced backfill strength and potential collapse of the backfill. The incorporation of pozzolanic wastes such as granulated blast furnace slag (GBFS) and silica fume (SF) into the binder phase appeared 
TABLE 1: Chemical properties of tailings, PC, and CHK used.

\begin{tabular}{lcccccccccc}
\hline Composition & $\mathrm{SiO}_{2}$ & $\mathrm{Al}_{2} \mathrm{O}_{3}$ & $\mathrm{Fe}_{2} \mathrm{O}_{3}$ & $\mathrm{CaO}$ & $\mathrm{MgO}$ & $\mathrm{Pb}$ & $\mathrm{Na}_{2} \mathrm{O}$ & $\mathrm{K}_{2} \mathrm{O}$ & $\mathrm{S}$ & Loss \\
\hline Tailings & 25.37 & 5.88 & 21.28 & 14.47 & 0.15 & 0.84 & 0.009 & 1.58 & 19.07 & 19.97 \\
PC & 25.26 & 6.38 & 4.05 & 54.67 & 2.68 & - & & - & 0.06 & - \\
$\mathrm{CHK}$ & 43.13 & 45.17 & 1.25 & 1.75 & 0.10 & - & - & - & 7.70 \\
\hline
\end{tabular}

TABle 2: Physical properties of tailings, PC, and CHK used.

\begin{tabular}{lcccccccccc}
\hline Physical properties & $\begin{array}{c}\mathrm{SSA} \\
\left(\mathrm{m}^{2} / \mathrm{kg}\right)\end{array}$ & $\begin{array}{c}G_{s} \\
(-)\end{array}$ & $\begin{array}{c}>90 \mu \mathrm{m} \\
(\%)\end{array}$ & $\begin{array}{c}>45 \mu \mathrm{m} \\
(\%)\end{array}$ & $\begin{array}{c}D_{10} \\
(\mu \mathrm{m})\end{array}$ & $\begin{array}{c}D_{30} \\
(\mu \mathrm{m})\end{array}$ & $\begin{array}{c}D_{60} \\
(\mu \mathrm{m})\end{array}$ & $\begin{array}{c}C_{u} \\
(-)\end{array}$ & $\begin{array}{c}C_{c} \\
(-)\end{array}$ & $\begin{array}{c}<20 \mu \mathrm{m} \\
(\%)\end{array}$ \\
\hline Tailings & 633.8 & 3.0 & 1.07 & 7.28 & 1.50 & 4.55 & 14.68 & 9.8 & 0.94 & 73.67 \\
PC & 461.9 & 3.1 & - & 5.67 & 5.12 & 9.19 & 18.28 & 3.6 & 0.90 & 65.65 \\
CHK & 588.1 & 2.6 & 1.44 & 13.11 & 1.31 & 4.8 & 17.97 & 13.72 & 0.98 & 68.69 \\
\hline
\end{tabular}

to mitigate the strength losses in the long term although the initial rate of development of strength of CPB samples tended to slow down with increasing the dosage of these pozzolanic wastes in the binder phase $[13,14]$. Therefore, binder properties, that is, its sulphate resistance, are of practical importance for $\mathrm{CPB}$ of sulphide-rich tailings. Metakaolin (MK) replacement of cement was found to be effective in improving the resistance of concrete to sulphate attack [16]. "Lower $\mathrm{Ca} / \mathrm{Si}$ ratios indicate the improvement of compressive strength [17]." The MK used in this study shows lower $\mathrm{Ca} / \mathrm{Si}$ ratio. However, reports about the effect of calcined hard kaolin $(\mathrm{CHK})$ with metakaolin on the short- and long-term strength and stability of CPB of fine tailings with sulphide (mainly pyrite) (19.07 wt.\% S) are scare.

Given the problems mentioned above, the main objectives of this study are as follows:

(1) To investigate the effect of $\mathrm{CHK}$ replacement to $\mathrm{PC}$ on the properties of CPB mixtures.

(2) To investigate the effect of CHK replacement to PC on unconfined compressive strength (UCS) development of CPB.

(3) To investigate the mechanism of the short- and longterm strength and stability of CPB of fine tailings with sulphide.

\section{Materials and Methods}

2.1. Tailings and Binder. The fine tailings sample used in this study is obtained from an underground lead-zinc mine located in the south of China. The fine tailings are a highly hydrous tailings slurry with $63 \mathrm{wt} . \%$ solid concentration, which is produced by thickening the overflow tailings with 12 wt.\% solid concentration derived from the top of vertical sand storehouse. Chemical compositions of the tailings are showed in Table 1. Particle size analysis of the tailings indicates that the tailings can be classified as a fine size tailings material since $73.67 \mathrm{wt} \%$ of the sample is finer than $20 \mu \mathrm{m}$ in size (Table 2). The tailings sample is determined to be medium-grade sulphide (19.07 wt.\% S) (Table 1). A mineralogical analysis is performed on the tailings via $\mathrm{X}$-ray diffraction (XRD). The main minerals in the tailings are quartz, pyrite, calcium carbonate, dolomite, and muscovite, in which pyrite is the major sulphide mineral (Figure 1(a)).

The binder used in this study is Portland cement (PC). The PC consisted of silicate cement that satisfied the Chinese standards for "Universal Portland Cement" (GB 175-2007). The chemical compositions and physical properties of the PC are shown in Tables 1 and 2. The main materials in the PC are cement clinker (i.e., tricalcium silicate, dicalcium silicate, tricalcium aluminate, and tetracalcium aluminoferrite) and gypsum (Figure 1(b)).

2.2. Admixtures. One type of calcined hard kaolin $(\mathrm{CHK})$ is used as mineral admixture in this study. Pozzolanic activity index can be reflected by the absorption ability of calcium hydroxide. The CHK used in this study is commercially available and with the absorption ability of $1050 \mathrm{mg} \mathrm{Ca}(\mathrm{OH})_{2} / \mathrm{g}$ $\mathrm{CHK}$. The $\mathrm{CHK}$ is obtained by calcining coal-measure hard kaolinite and grinding. China is rich in coal hard kaolinite reserves, which belong to sedimentary kaolinite and occur in the coal seam roof and floor and mezzanine. The chemical and physical properties of the CHK are shown in Tables 1 and 2. The main crystal minerals in the CHK are kaolinite and quartz, while the amorphous form mineral (i.e., metakaolin, $\mathrm{MK}$ ) in the CHK is also obvious (Figure 1(c)).

2.3. Mixing Water. Tap water is used in this study. The effect of the sulphate ions in tap water can be neglected.

2.4. Slump and Wet Density Tests. The workability of CPB mixtures is measured by the slump of CPB mixtures. The high slump and low bleeding rate value of $C P B$ mixtures indicate that the $\mathrm{CPB}$ mixture has good workability. The bleeding rate value of all CPB mixtures in this study is all $\leq 2 \mathrm{wt} . \%$.

The slumps of the samples are tested according to the Chinese standard (GB/T 50080-2002). The desired slump value in this study is $180 \mathrm{~mm}$.

2.5. Preparation and Testing of CPB Samples. The UCS criteria to be achieved in this study are to produce the desired 28-day strength of $\geq 2.0 \mathrm{MPa}$ and the maintenance of the stability (i.e., $\geq 2.0 \mathrm{MPa}$ UCS at curing $360 \mathrm{~d}$ ) according to requirement of mining technology. 


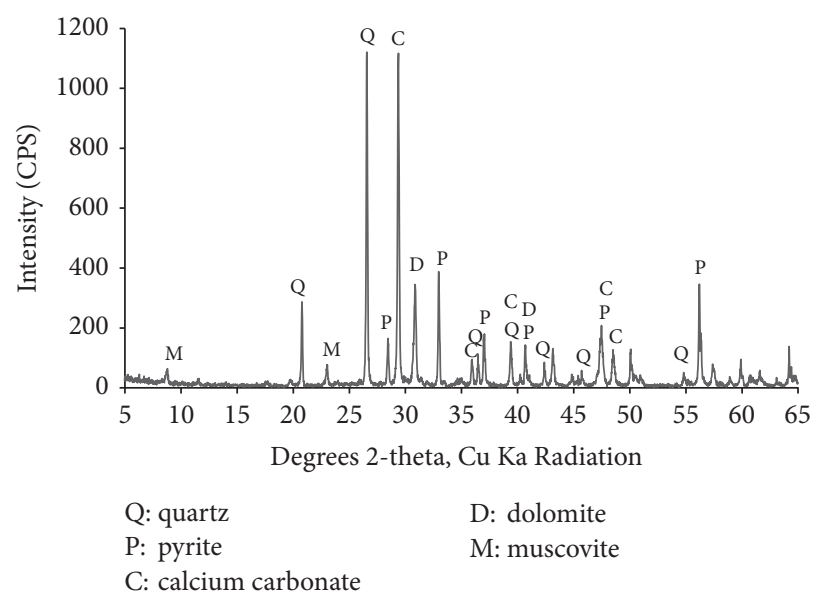

(a)

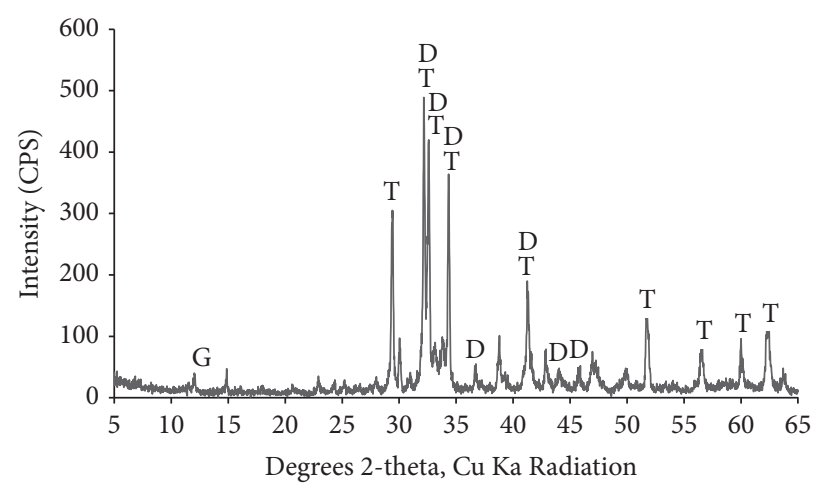

T: tricalcium silicate

D: dicalcium silicate

G: gypsum

(b)

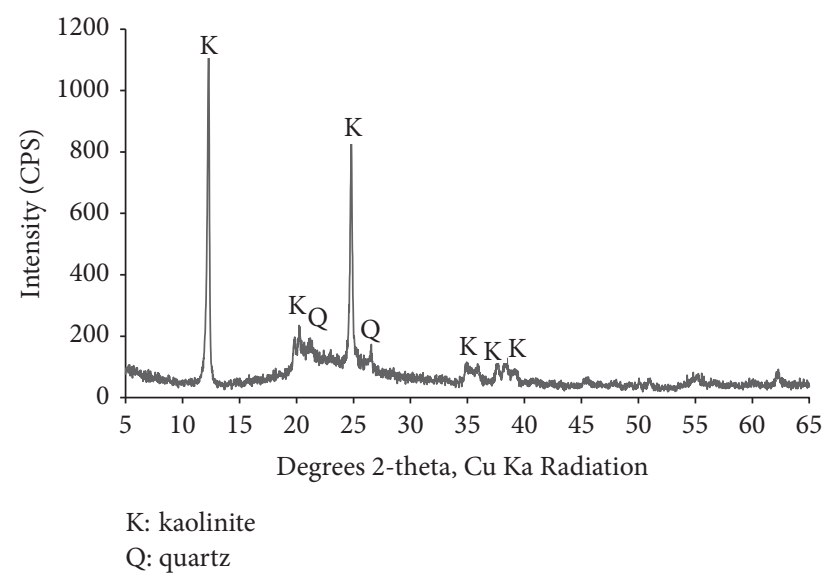

(c)

FIGURE 1: XRD profiles of tailings (a), PC (b), and CHK (c).

TABLE 3: Mix proportions and partial properties of CPB mixture.

\begin{tabular}{|c|c|c|c|c|c|c|c|c|c|}
\hline \multirow[b]{2}{*}{ Number } & \multicolumn{5}{|c|}{ Mix proportions } & \multicolumn{4}{|c|}{ Partial properties of $\mathrm{CPB}$ mixture } \\
\hline & $\begin{array}{c}\text { Tailings } \\
\text { slurry } \\
\text { /g }\end{array}$ & $\begin{array}{l}\text { water } \\
/ g\end{array}$ & $\begin{array}{l}\mathrm{PC} \\
/ \mathrm{g}\end{array}$ & $\begin{array}{l}\mathrm{CHK} \\
/ \mathrm{g}\end{array}$ & $\begin{array}{c}\mathrm{RL}^{(2)} \\
/ \%\end{array}$ & $\begin{array}{c}\text { Solids } \\
\text { content } \\
\text { /wt.\% }\end{array}$ & $\begin{array}{l}\text { Water to } \\
\text { cement } \\
\text { ratio/\% }\end{array}$ & $\begin{array}{l}\text { Wet density } \\
/\left(\mathrm{kg} / \mathrm{m}^{3}\right)\end{array}$ & $\begin{array}{l}\text { Slump } \\
/ \mathrm{mm}\end{array}$ \\
\hline 1 & 1000 & 92.5 & 157.5 & 0 & 0 & 63 & 58.7 & 1785 & 185 \\
\hline 2 & 1000 & 92.5 & 133.9 & 23.6 & 15 & 63 & 69.1 & 1785 & 180 \\
\hline 3 & 1000 & 92.5 & 110.25 & 47.25 & 30 & 63 & 83.9 & 1795 & 180 \\
\hline 4 & 1000 & 92.5 & 78.75 & 78.75 & 50 & 63 & 78.8 & 1815 & 175 \\
\hline
\end{tabular}

Binder (including PC and CHK) dosage in this study is kept constant at $20 \mathrm{wt} . \%$ of total solids. The required amounts (see Table 3) of CPB ingredients (tailings slurry, PC, CHK, and mix water) are thoroughly mixed in a double spiral mortar mixer for about $5 \mathrm{~min}$ to ensure paste homogeneity. Immediately after mixing, samples are poured into $70.7 \mathrm{~mm}$ $\times 70.7 \mathrm{~mm} \times 70.7 \mathrm{~mm}$ iron molds. Excess water (i.e., drain away water) in the samples could separate out from the seam between the broadsides and the baseboard of the iron molds. Then, the open-top samples are placed in a humidity chamber set at $20 \pm 1^{\circ} \mathrm{C}$ and $90 \% \mathrm{RH}$ for curing. In total, 84 samples were made and cured for 7, 28, 56, 90, 150, 210, 270, and 360 days. Then the CPB samples are tested for unconfined compressive strength (UCS) according to the Chinese standard (JGJ/T 70-2009), in which the loading rate is $0.25 \sim 1.5 \mathrm{KN} / \mathrm{s}$. Prior to a UCS test, the sizes of a sample are 
rectified to get valid press surfaces. UCS tests are performed using a computer-controlled mechanical press, which had a load capacity of $100 \mathrm{KN}$.

2.6. XRD and MIP Studies. After compression testing, representative samples are taken from locations as far as possible from the shear plane to avoid stress concentration effects. The representative samples are treated with acetone and then dried in an oven maintained at $60^{\circ} \mathrm{C}$ to halt further hydration prior to X-ray diffraction (XRD) and mercury intrusion porosimeter (MIP) studies.

The XRD analysis is performed using a $\mathrm{D} / \mathrm{max}-2500 \mathrm{PC}$ $\mathrm{X}$-ray diffractometer from Japan with a copper target with a $2 \theta$ range of $4^{\circ}-60^{\circ}$ and a scanning speed of $2^{\circ} / \mathrm{min}$ to examine the mineralogical compositions of $\mathrm{CPB}$ samples after the curing process.

The MIP used in this study is an AutoPore IV 9500 V1.05. Applying pressures ranged from 0 to $414 \mathrm{MPa}(60,000 \mathrm{psi})$, allowing throat pore diameter measurements down to $0.003 \mu \mathrm{m}$. MIP is analyzed according to the ISO 15901-1: 2005 standard. In this study, mercury surface tension $\sigma$ and mercury contact angle $\theta$ are taken as 485 dynes $/ \mathrm{cm}$ and $130^{\circ} \mathrm{C}$, respectively.

\section{Results and Discussion}

3.1. Effect of CHK on the Workability of CPB Mixtures. The influence of $\mathrm{CHK}$ replacement level to PC on the workability of CPB mixtures is illustrated in Table 3. Table 3 shows that the slump of $\mathrm{CPB}$ mixture tends to decrease with increasing CHK replacement level to PC at the same solids content. However, the wet density of $\mathrm{CPB}$ mixture tends to increase with increasing $\mathrm{CHK}$ replacement level to $\mathrm{PC}$ at the same solids content. Fineness and surface characteristic of CHK can be main influence factors.

3.2. Effect of $C H K$ on the Strength Development of $C P B$ Mixtures. The effect of $\mathrm{CHK}$ replacement level to $\mathrm{PC}$ on the strength development of CPB samples over a curing period of 360 days is illustrated in Figure 2. Mix proportions and partial properties of CPB mixtures in Figure 2 are shown in Table 3.

Figure 2 shows that the UCS of the control sample (i.e., no $\mathrm{CHK}$ in binder) and the samples of $15 \mathrm{wt} . \% \mathrm{CHK}$ and $50 \mathrm{wt} . \% \mathrm{CHK}$ in binder tend to increase over a curing period of $90 \mathrm{~d}, 28 \mathrm{~d}$, and $28 \mathrm{~d}$, respectively; thereafter, the UCSs tend to decrease. The control sample has $32.8 \%$ losses in strength over the curing period between 90 days and 360 days. The samples of 15 wt.\% CHK and 50 wt.\% $\mathrm{CHK}$ in binder have $38.6 \%$ and $57.2 \%$ losses in strength over the curing period between 28 days and 360 days, respectively. The $28 \mathrm{~d}$ UCS of CPB sample containing $30 \mathrm{wt} . \% \mathrm{CHK}$ in binder achieves the desired 28-day strength of $\geq 2.0 \mathrm{MPa}$. In addition, the $\mathrm{CPB}$ samples containing $30 \mathrm{wt}$ \% $\mathrm{CHK}$ in binder are observed to develop consistently over a curing period of 360 days and have $26.1 \%$ increase in strength over the curing period between 28 days and 360 days. These findings suggest that $20 \mathrm{wt}$.\% binder in total solids and $30 \mathrm{wt} . \%$ CHK in binder are extremely effective for increasing the strength and stability

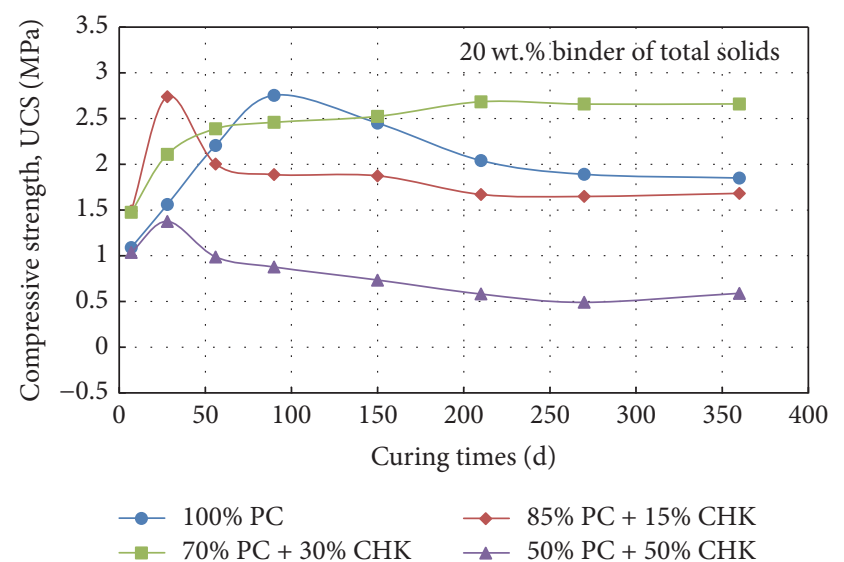

FIGURE 2: The influence of CHK replacement level on the strength development of CPB samples.

in short and long terms of $\mathrm{CPB}$ of fine tailings with sulphide (19.07 wt.\% S).

When the fine tailings with pyrite $\left(\mathrm{FeS}_{2}\right)$ mix with binder and water, a series of complex chemical reactions happen. First of all, the hydration reaction between $\mathrm{PC}$ and water produces hydrated calcium silicate gel $(\mathrm{C}-\mathrm{S}-\mathrm{H})$, portlandite $\left(\mathrm{Ca}(\mathrm{OH})_{2}\right)$, and so forth. Secondly, the sulphide phases such as pyrite present in $\mathrm{CPB}$ could undergo oxidation under the curing conditions in the presence of air and moisture. The oxidation of pyrite yields acid and sulphate (1). The former can attack and destruct $\mathrm{C}-\mathrm{S}-\mathrm{H}$ bonds while the latter can react with portlandite $\left(\mathrm{Ca}(\mathrm{OH})_{2}\right)$ and tricalcium aluminate $\left(\mathrm{C}_{3} \mathrm{~A}\right)$ to form secondary gypsum (2) and ettringite (3) with these leading to the expansion and development of microcracks in cured CPB. The formation of secondary gypsum and ettringite with expansive properties was claimed to be responsible for the reduction of strength of $\mathrm{CPB}$ samples after 56 and 90 days. However, the formation of secondary ettringite is not observed by XRD analyses in the $\mathrm{CPB}$ samples in this study (see Figures 3(a) and 3(b)).

$$
\begin{gathered}
4 \mathrm{FeS}_{2}+15 \mathrm{O}_{2}+8 \mathrm{H}_{2} \mathrm{O} \longrightarrow 2 \mathrm{Fe}_{2} \mathrm{O}_{3}+8 \mathrm{SO}_{4}{ }^{2-}+16 \mathrm{H}^{+} \\
\mathrm{Ca}(\mathrm{OH})_{2}+\mathrm{SO}_{4}{ }^{2-}+2 \mathrm{H}_{2} \mathrm{O} \longrightarrow \\
\mathrm{CaSO}_{4} \cdot 2 \mathrm{H}_{2} \mathrm{O}+2 \mathrm{OH}^{-} \\
3 \mathrm{CaO} \cdot \mathrm{Al}_{2} \mathrm{O}_{3}+3 \mathrm{CaSO}_{4} \cdot 2 \mathrm{H}_{2} \mathrm{O}+30 \mathrm{H}_{2} \mathrm{O} \longrightarrow \\
3 \mathrm{CaO} \cdot \mathrm{Al}_{2} \mathrm{O}_{3} \cdot 3 \mathrm{CaSO}_{4} \cdot 32 \mathrm{H}_{2} \mathrm{O}
\end{gathered}
$$

Figure 3 shows that the quantity of expansive gypsum of $\mathrm{CPB}$ with $100 \%$ PC (a) is obviously higher than that of CPB with $70 \%$ PC $+30 \%$ CHK (b) at 360 days. The results can be explained by the following mechanisms. First, the replacement of a portion of $\mathrm{PC}$ with $\mathrm{CHK}$ reduces the total amount of PC clinker in binder of CPB samples. The second mechanism is through the pozzolanic reaction between the $\mathrm{MK}$ in $\mathrm{CHK}$ and calcium hydroxide released during the hydration of PC, which consumes part of the calcium hydroxides leading to decreasing the quantity of expansive gypsum [15]. 


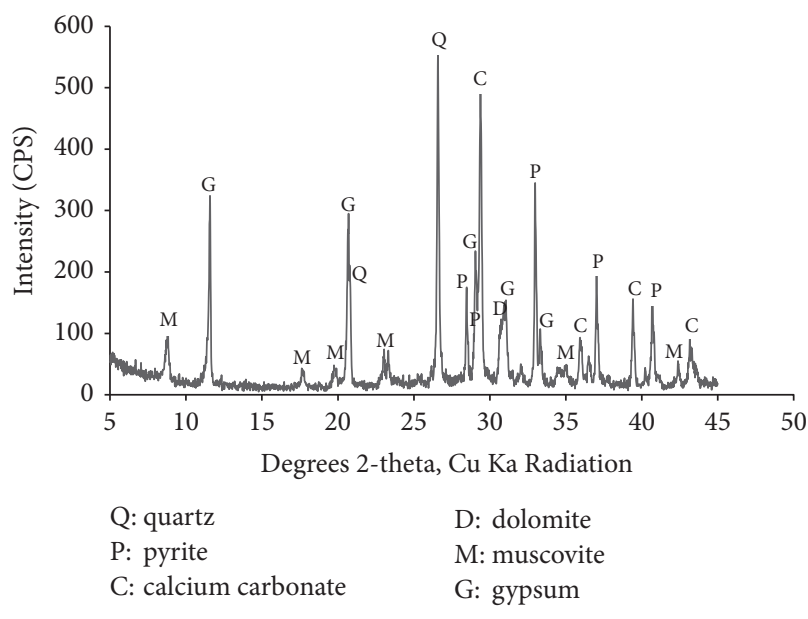

(a)

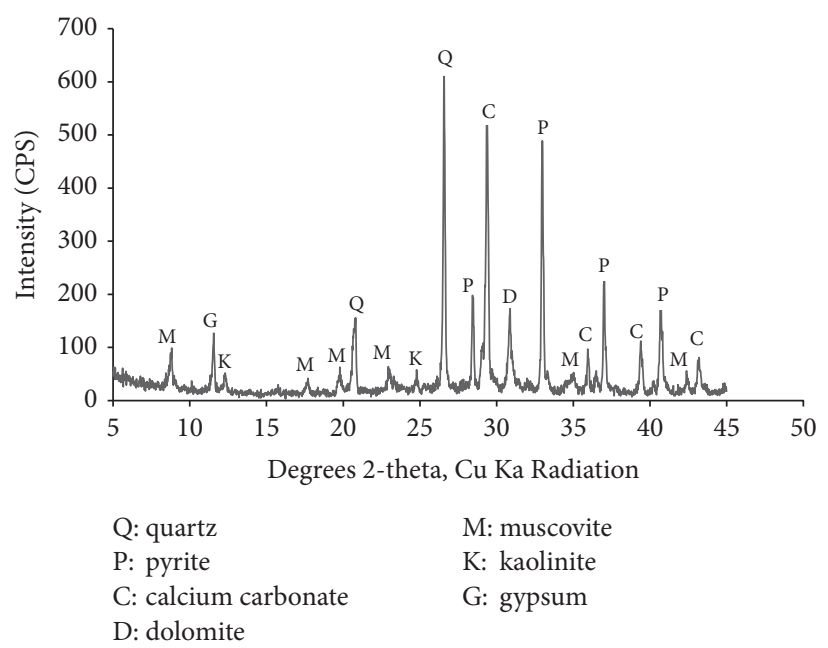

(b)

FIgURE 3: XRD profile of CPB with 100\% PC (a) and 70\% PC + 30\% CHK (b) at 360 days.

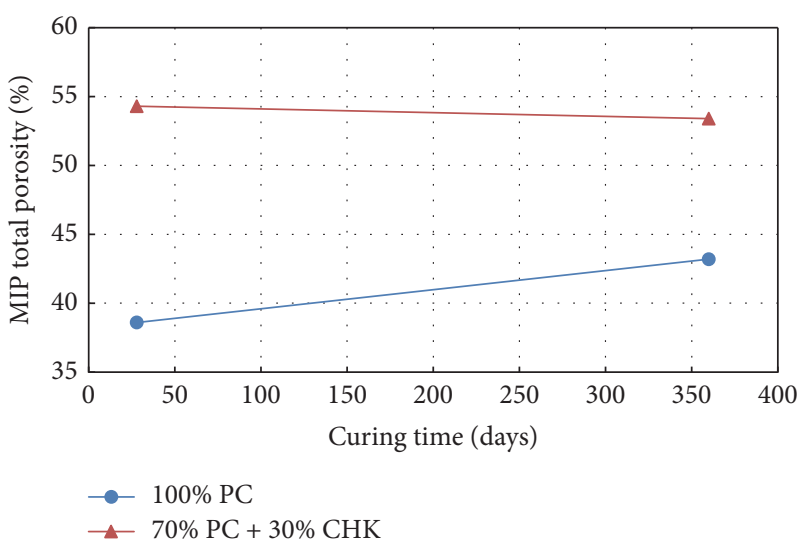

FIGURE 4: Relationships between MIP total porosity and curing time of CPB samples.

It is well known that pore structure can cause significant effects on the strength of $\mathrm{CPB}$. Figure 4 shows that relationships between MIP total porosity and curing time of CPB samples. For CPB samples with the same mixing proportion, the lower the MIP total porosity, the greater the UCS. For CPB samples with different mixing proportion, UCS is not strictly correlated with the MIP total porosity.

Figure 5 shows the changes in incremental pore size distribution (PSD) curves for 28 and 360 cured CPB samples. According to the definition of the capillary pore, pores $\geq 0.3 \mu \mathrm{m}$ correspond to the main interconnected capillary porosity network. The porosity of the fine pore for pore diameter $<0.3 \mu \mathrm{m}$ is obviously higher in $\mathrm{CPB}$ sample with $\mathrm{CHK}$ than in $\mathrm{CPB}$ without $\mathrm{CHK}$, regardless of curing time. The reason of gaining the result is that the formation of secondary hydrated calcium silicate gel $(\mathrm{C}-\mathrm{S}-\mathrm{H})$ by the pozzolanic reaction is effective in filling and segmenting large capillary pores into small, discontinuous capillary pores through pore size refinement, which increases the UCS of
CPB samples. An additional potential reason of more finer pores in $\mathrm{CHK}$ is the filler effect role of the admixture.

Figure 6 shows visual appearance of CPB samples. In visual appearance of $\mathrm{CPB}$ samples, the surface cracks of $\mathrm{CPB}$ sample with $100 \%$ PC at 360 days can be clearly identified while no surface cracks can be detected in CPB sample with $70 \% \mathrm{PC}+30 \% \mathrm{CHK}$ at 360 days.

Figure 7 shows schematic diagram of bonding strength and expansion stress development in $\mathrm{CPB}$ samples. The bonding strength of CPB sample increases with increasing curing times due to the increase of hydration products and the porosity of the fine pore for pore diameter $<0.3 \mu \mathrm{m}$. The expansion stress of $\mathrm{CPB}$ sample increases with increasing the quantity of secondary gypsum and ettringite within CPB sample. When the expansion stress (ES1 in Figure 7) produced by forming secondary gypsum and ettringite in CPB sample exceeds the bonding strength (BS in Figure 7) of CPB sample, the sample cracks and MIP total porosity increase, which lead to the decrease of the UCS of the samples such as number 1 , number 2 , and number 4 in Table 3 . However, the secondary gypsum in certain quantity could also fill the voids within CPB. The expansion stress (ES2 in Figure 7) is always less than the bonding strength (BS in Figure 7) within CPB. This in turn leads to a decreased porosity and higher short- and long-term strength of $\mathrm{CPB}$ sample such as number 3 in Table 3 . This is a conclusion in this study that $\mathrm{CPB}$ sample containing $30 \% \mathrm{CHK}$ replacement level to PC shows excellent short- and long-term mechanical performances.

\section{Conclusions}

This study presents the results for effect of calcined hard kaolin with metakaolin on the short- and long-term strength and stability of CPB of fine tailings with sulphide. Based on the results obtained from this study, the following conclusions may be warranted: 

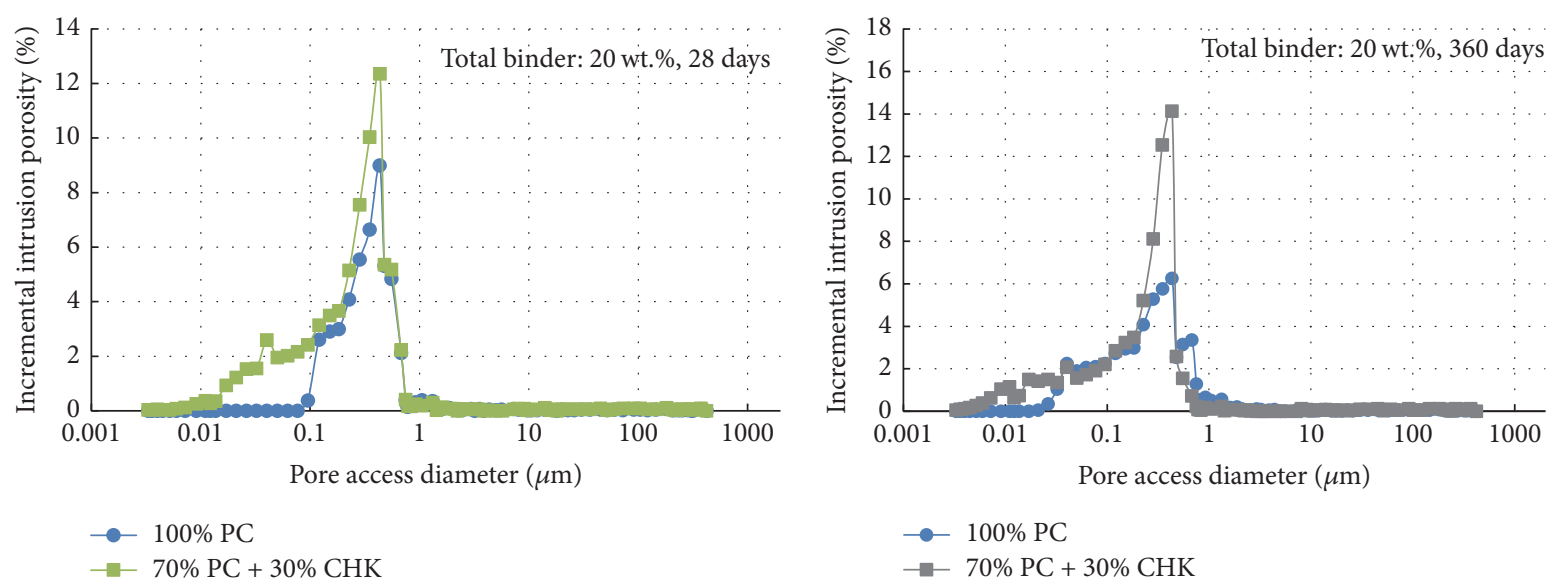

FIGURE 5: Relationships between incremental Hg intrusion porosity and pore access diameter.

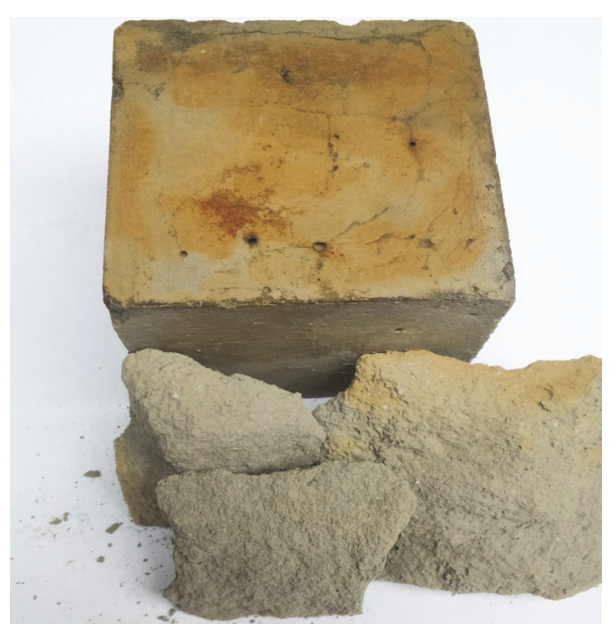

(a)

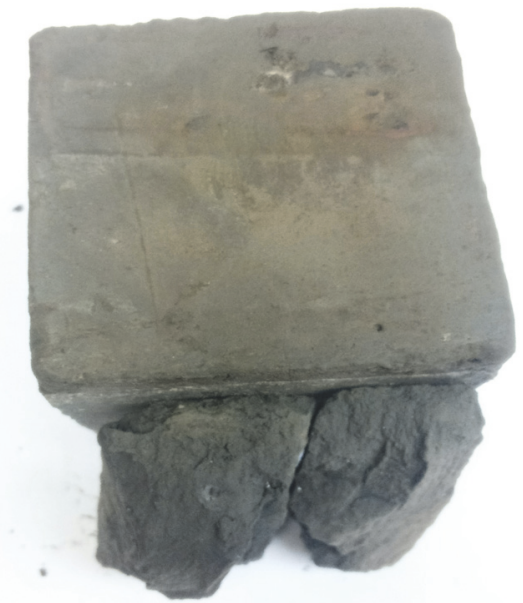

(b)

FIgURE 6: Visual appearance of CPB with 100\% PC (a) and 70\% PC $+30 \%$ CHK (b) at 360 days.

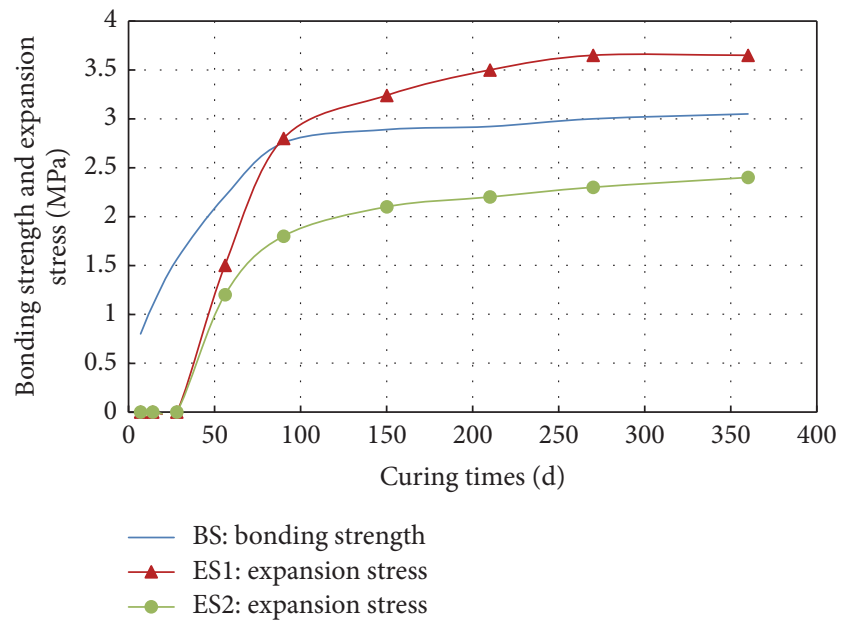

FIGURE 7: Schematic diagram of bonding strength and expansion stress development in CPB samples.
(1) $\mathrm{CPB}$ containing $30 \mathrm{wt} \% \mathrm{CHK}$ replacement to $\mathrm{PC}$ achieves the desired strength value (i.e., $\geq 2.0 \mathrm{MPa}$ UCS at curing $360 \mathrm{~d}$ ).

(2) $\mathrm{CPB}$ without $\mathrm{CHK}$ has $32.8 \%$ losses in strength over the curing period between 90 days and 360 days. CPB containing $30 \mathrm{wt}$ \% $\mathrm{CHK}$ replacement level to $\mathrm{PC}$ has $26.1 \%$ increase in strength over the curing period between 28 days and 360 days.

(3) The quantity of expansive gypsum of CPB containing 30 wt.\% CHK replacement to PC is obviously less than that of $\mathrm{CPB}$ without $\mathrm{CHK}$. The porosity of the fine pore for pore diameter $<0.3 \mu \mathrm{m}$ is obviously higher in $\mathrm{CPB}$ containing $30 \mathrm{wt} . \% \mathrm{CHK}$ replacement to $\mathrm{PC}$ than in $\mathrm{CPB}$ without $\mathrm{CHK}$, regardless of curing time.

(4) When the expansion stress produced by forming secondary gypsum and ettringite in CPB samples exceeds the bonding strength of CPB samples, the 
sample cracks and MIP total porosity increase, which lead to the decrease of the UCS of the sample, and vice versa.

\section{Conflicts of Interest}

The authors declare that they have no conflicts of interest.

\section{Acknowledgments}

This study is funded by the National Natural Science Foundation of China (Project no. 51274174) and National Key Research and Development Program (Project no. 2016YFC0600709). The authors would like to thank Professor Dongwu Chang of Zhengzhou University for his assistance with the MIP analysis.

\section{References}

[1] Z. Wei, G. Yin, G. Li, J. G. Wang, L. Wan, and L. Shen, "Reinforced terraced fields method for fine tailings disposal," Minerals Engineering, vol. 22, no. 12, pp. 1053-1059, 2009.

[2] R. Zhou, "Application of cemented filling with classified tailings in Wushan copper mine," Non-Ferrous Metal (Part of Mine), vol. 63, no. 3, pp. 1-5, 2010 (Chinese).

[3] D. Chen and W. D. Song, "Experimental study on performance of cemented filling with classified tailings in Laixi gold mine," Non-Ferrous Metal (Part of Mine), vol. 67, no. 4, pp. 54-57, 2015 (Chinese).

[4] M. Pokharel and M. Fall, "Combined influence of sulphate and temperature on the saturated hydraulic conductivity of hardened cemented paste backfill," Cement and Concrete Composites, vol. 38, pp. 21-28, 2013.

[5] M. Benzaazoua, J. Quellet, S. Servant, P. Newman, and R. Verburg, "Cementitious backfill with high sulfur content: physical, chemical and mineralogical characterization," Cement and Concrete Research, vol. 29, no. 5, pp. 719-725, 1999.

[6] Z. D. Liu, Q. Li, and Z. H. Fu, "Investigation on the resources development and utilization of the storage tailings of Fankou lead-zinc mine," Mining Technology, vol. 18, no. 5, pp. 101-103, 2008 (Chinese).

[7] J. Aguilar, C. Dorronsoro, E. Fernández et al., "Soil pollution by a pyrite mine spill in Spain: evolution in time," Environmental Pollution, vol. 132, no. 3, pp. 395-401, 2004.

[8] L. M. Zhai, T. B. Chen, X. Y. Liao, X. L. Yan, L. X. Wang, and H. Xie, "Pollution of agricultural soils resulting from a tailing spill at a pb-zn mine: a case study in huanjiang, guangxi province," Acta Scientiae Circumstantia, vol. 28, no. 6, pp. 1206-1211, 2008.

[9] A. Tariq and E. K. Yanful, "A review of binders used in cemented paste tailings for underground and surface disposal practices," Journal of Environmental Management, vol. 131, pp. 138-149, 2013.

[10] M. Benzaazoua, B. Bussière, I. Demers, M. Aubertin, É. Fried, and A. Blier, "Integrated mine tailings management by combining environmental desulphurization and cemented paste backfill: Application to mine Doyon, Quebec, Canada," Minerals Engineering, vol. 21, no. 4, pp. 330-340, 2008.

[11] A. Kesimal, E. Yilmaz, B. Ercikdi, I. Alp, and H. Deveci, "Effect of properties of tailings and binder on the short-and longterm strength and stability of cemented paste backfill," Materials Letters, vol. 59, no. 28, pp. 3703-3709, 2005.
[12] B. Ercikdi, A. Kesimal, F. Cihangir, H. Deveci, and İ. Alp, "Cemented paste backfill of sulphide-rich tailings: importance of binder type and dosage," Cement and Concrete Composites, vol. 31, no. 4, pp. 268-274, 2009.

[13] B. Ercikdi, F. Cihangir, A. Kesimal, H. Deveci, and I. Alp, "Utilization of industrial waste products as pozzolanic material in cemented paste backfill of high sulphide mill tailings," Journal of Hazardous Materials, vol. 168, no. 2-3, pp. 848-856, 2009.

[14] M. Fall and M. Pokharel, "Coupled effects of sulphate and temperature on the strength development of cemented tailings backfills: portland cement-paste backfill," Cement and Concrete Composites, vol. 32, no. 10, pp. 819-828, 2010.

[15] S. Ouellet, B. Bussière, M. Aubertin, and M. Benzaazoua, "Microstructural evolution of cemented paste backfill: mercury intrusion porosimetry test results," Cement and Concrete Research, vol. 37, no. 12, pp. 1654-1665, 2007.

[16] N. M. Al-Akhras, "Durability of metakaolin concrete to sulfate attack," Cement and Concrete Research, vol. 36, no. 9, pp. 17271734, 2006.

[17] S. Dadsetan and J. Bai, "Mechanical and microstructural properties of self-compacting concrete blended with metakaolin, ground granulated blast-furnace slag and fly ash," Construction and Building Materials, vol. 146, pp. 658-667, 2017. 

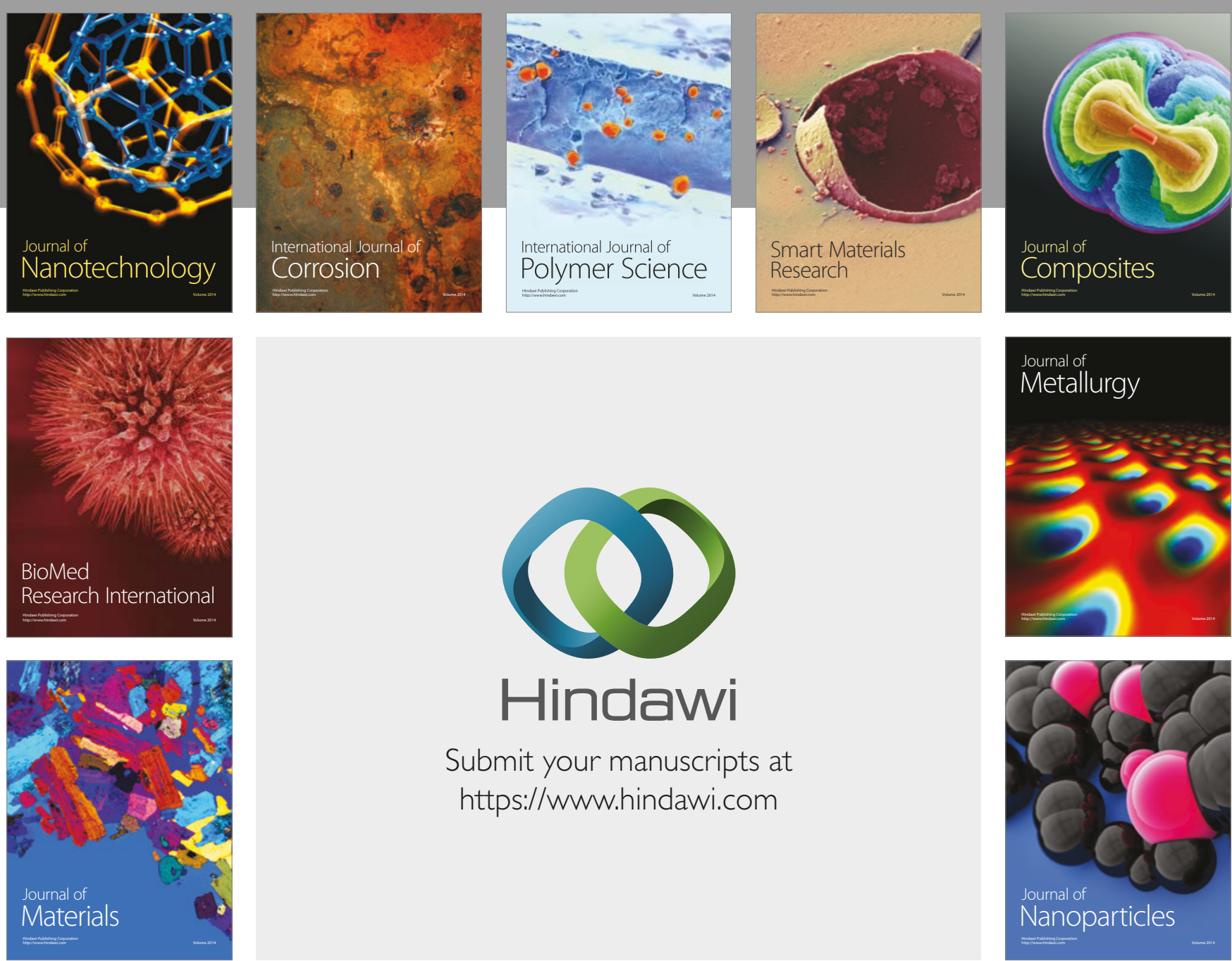

\section{Hindawi}

Submit your manuscripts at

https://www.hindawi.com
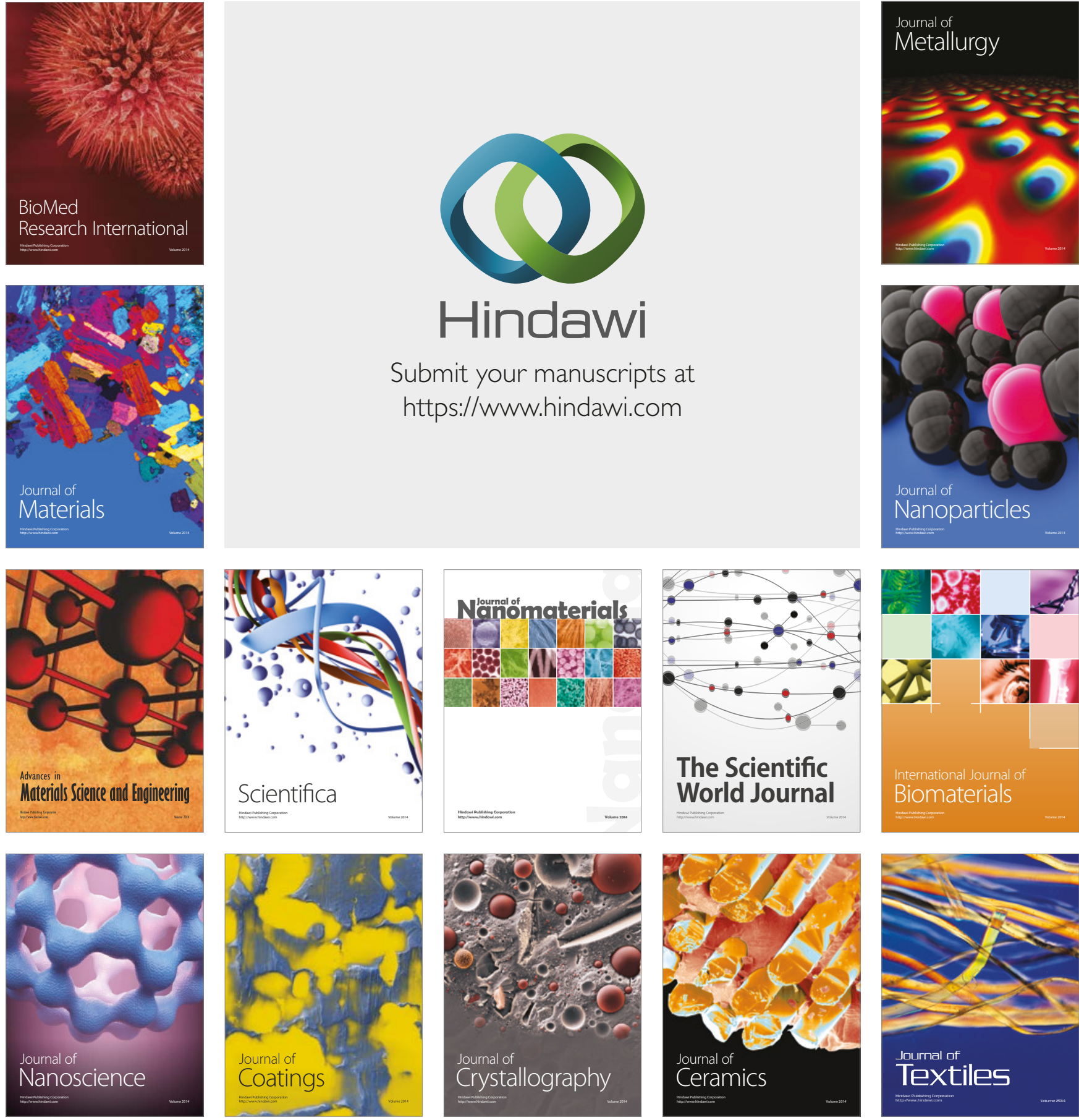

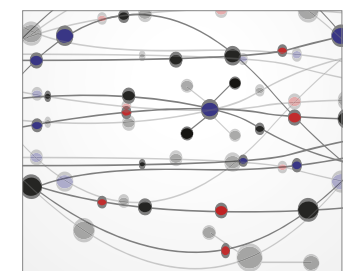

The Scientific World Journal
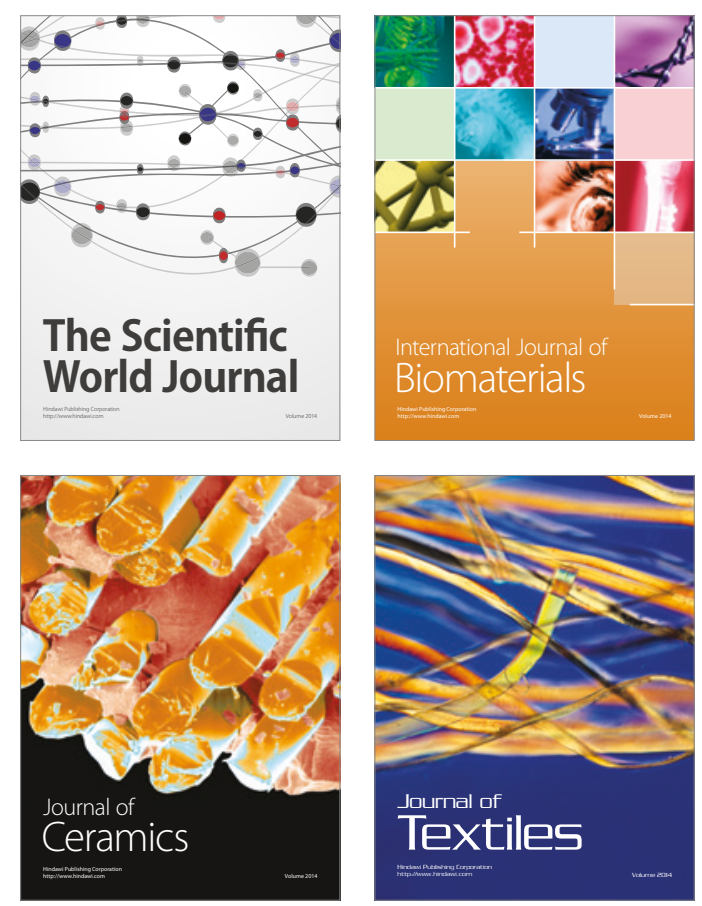